\title{
Chilling Temperature Storage Changes the Inorganic Phosphate Pool Distribution in Cherimoya (Annona cherimola) Fruit
}

\author{
Teresa Muñoz, Jesús Ruiz-Cabello, ${ }^{2}$ Antonio D. Molina-García, ${ }^{3}$ María I. Escribano, and \\ Carmen Merodio ${ }^{1}$ \\ Departamento de Ciencia y Tecnología de Productos Vegetales, Instituto del Frío, Consejo Superior de \\ Investigaciones Científicas, Ciudad Universitaria, E-28040-Madrid, Spain
}

AdDitional INDEX WORDS. acidification, energy, malic acid metabolism, pH, nuclear magnetic resonance.

\begin{abstract}
Phophorous nuclear magnetic resonance $\left({ }^{31}\right.$ P-NMR) spectroscopy was used to study the vacuolar and cytoplasmic pH and the inorganic phosphate (Pi) pool distribution in 'Fino de Jete' cherimoya (Annona cherimola Mill.) fruit stored at a chilling temperature $\left(6^{\circ} \mathrm{C}\right)$. Fruit stored at the ripening temperature $\left(20{ }^{\circ} \mathrm{C}\right)$ for 3 days were used as a control. ${ }^{31} \mathrm{P}-\mathrm{NMR}$ results confirmed that $6^{\circ} \mathrm{C}$ storage caused cytoplasmic acidosis (a decrease of $0.72 \pm 0.08 \mathrm{pH}$ units) and a notable increase in the amount of $\mathrm{Pi}$ in the cytoplasm. Spectra of perchloric acid extracts also revealed that storage at $6^{\circ} \mathrm{C}$ was associated with an increase in the total amount of $\mathrm{Pi}$ and phosphorylated metabolites. Moreover, perfusion experiments with a phosphate medium confirmed the preferential accumulation of $\mathrm{Pi}$ in the cytoplasm in chilled tissues. Specific activation of phosphoenolpyruvate carboxylase (PEPC) $\left(32.1 \pm 1.7 \mu \mathrm{mol} \cdot \mathrm{min}^{-1} \cdot \mathrm{mg}^{-1}\right)$ was observed in those fruit. In chilled fruit the amount of ADP was held at steady-state levels and ATP levels increased, contrary to observations for ripe fruit, where the pool of total nucleotides decreased beyond the point of NMR detection. Fruit stored at $6^{\circ} \mathrm{C}$ exhibited a low respiration rate, but metabolism was not arrested and an increase in total soluble solid contents was also observed.
\end{abstract}

Low temperature storage is used to prolong the shelf life of fruit and vegetables. Unfortunately, tropical and subtropical fruit are chilling-sensitive and storage below critical temperatures is often responsible for substantial losses (Wang, 1982). Successful control of fruit storage at low temperature entails a recognition of the importance of the metabolic processes existing in the fruit at the time of harvest as well as the unexpected biological responses accompanying storage at chilling temperatures.

Yoshida (1994) reported that low temperature-induced cytoplasmic acidosis in cultured mung bean [Vigna radiata (L.) R. Wilcz. Csyn. Phaseolus aureus Roxb.] cells and suggested that acidification of the cytoplasm is common in those very chilling-sensitive plants. Some of the beneficial effects of specific postharvest technologies in overcoming chilling injury are related to activation of reactions implicated in the maintenance of the $\mathrm{pH}$-stat of plant cells. Of these, accumulation of $\gamma$-aminobutyric acid or polyamines has been proposed as a low temperature adaptive response (Crawford et al., 1994; Merodio et al., 1998; Muñoz et al., 1999). These results are indirect evidence of the loss of plant cell buffering capacity at a chilling temperature. There is, however, no information available regarding the response of intracellular $\mathrm{pH}$ in fruit after storage at low temperatures.

The role of cellular $\mathrm{pH}$ as a regulator of metabolism is widely accepted, and small, highly regulated $\mathrm{pH}$ changes have been identified as a signal transduction mechanism in a wide variety of biological systems (Kurkdjian and Guern, 1989; Lapous et al.,

Received for publication 26 Oct. 1999. Accepted for publication 23 Sept. 2000. This research was supported by Comisión Interministerial de Ciencia y Tecnología (CICYT) grant (ALI99-0954-C03-01). The authors are grateful to Palmira Villa for technical assistance provided in connection with NMR. The cost of publishing this paper was defrayed in part by the payment of page charges. Under postal regulations, this paper therefore must be hereby marked advertisement solely to indicate this fact.

'Corresponding author e-mail: merodio@if.csic.es.

${ }^{2}$ Unidad de RMN and Departamento de Química Física II, Facultad de Farmacia, UCM, Ciudad Universitaria, E-28040-Madrid, Spain.

${ }^{3}$ Departamento de Ingeniería. Instituto del Frío (CSIC).
1998). Moreover, the capacity to regulate $\mathrm{pH}$ is a key factor in determining tissue survival under stressful conditions (Roberts et al., 1984a). According to Smith and Raven (1979), metabolic control of $\mathrm{pH}$ involves a combination of membrane transport and intracellular metabolism.

Numerous hypotheses have been proposed to explain mechanism(s) of chilling injury (Raison and Orr, 1990). It has long been thought that physical disruptions in cellular compartments containing ions and metabolites may be a cause of chilling injury in chilling-sensitive plants (Lyons, 1973). Tonoplast vesicles are highly sensitive to chilling and changes in the properties of the vacuolar proton pump in response to various kinds of stress have been reported (Lüttge and Ratajczak, 1997). Cherimoya fruit(Annona cherimola) have a high sensibility to low temperature and when stored at $6^{\circ} \mathrm{C}$ for 2 weeks lose their ability to ripen after transfer to $20{ }^{\circ} \mathrm{C}$, and shows skin browning, hardening and other external chilling symptoms (Alique et al., 1994). Moreover, cherimoyas have large vacuoles and an inherent high acid metabolism (Merodio and De La Plaza, 1997), that make these fruit suitable for the study of changes in the cytoplasmatic and vacuolar $\mathrm{pH}$ and phosphorylated metabolites associated with storage at chilling temperatures. The present study is an attempt to obtain insight into respiratory and acid metabolism and the disruption of intracellular $\mathrm{pH}$ homeostasis in cherimoyas during storage at chilling temperatures.

Phosphorus nuclear magnetic resonance $\left({ }^{31} \mathrm{P}-\mathrm{NMR}\right)$ spectroscopy has proved to be a useful and accurate approach in determining intracellular $\mathrm{pH}$ and in monitoring modifications in the pool size of endogenous phosphorylated compounds. This method relies on the fact that the chemical shift of ${ }^{31} \mathrm{P}$ in some phosphates is $\mathrm{pH}$ dependent. If accurate titration curves are available, $\mathrm{pH}$ can be determined from a measured resonance frequency, always keeping the tissue in a physiologically reasonable and controlled state throughout the experiment (Ratcliffe, 1994). Changes in $\mathrm{pH}$ and inorganic phosphate $(\mathrm{Pi})$ content have been studied under several different experimental conditions such as low $\mathrm{O}_{2}$ (Nanos and Kader, 1993; Roberts et al., 1984b), high $\mathrm{CO}_{2}$ (Siriphanich and Kader, 1986) or under acid loads (Guern et al., 1986). 
In this work, ${ }^{31} \mathrm{P}-\mathrm{NMR}$ spectroscopy was used to measure alterations by chilling temperature in the cytoplasmic and vacuolar Pi signals in cherimoya fruit. To test the effect of temperature storage on phosphate uptake, perfusion experiments with a phosphate-containing medium were performed. The energy state and respiratory metabolism of cherimoya fruit after storage at a ripening $\left(20^{\circ} \mathrm{C}\right)$ and a chilling temperature $\left(6^{\circ} \mathrm{C}\right)$ were also included. We also analyzed activities of phosphoenolpyruvate carboxylase (PEPC), malic dehydrogenase (MDH), and malic enzyme (ME) in relation to malic acid metabolism. We believe that a comprehensive study of cherimoya metabolism should yield information on dysfunctions resulting from chilling injury in chilling-sensitive fruit. This information may help to explain mechanism(s) underlying the conversion of developmental and environmental signals into changes in fruit metabolism during postharvest storage.

\section{Materials and Methods}

Plant material and treatment. 'Fino de Jete' cherimoya fruit free from physical and pathological defects were harvested in January (midseason), in Almuñecar, Granada, Spain and shipped to the Instituto del Frío laboratory, Madrid within $12 \mathrm{~h}$. Mature-green fruit (light-green fruit, carpels with shallow ridges) of uniform shape weighing 250 to $260 \mathrm{~g}$ were divided randomly into two groups of 40 fruit and stored in the dark at 20 and $6^{\circ} \mathrm{C}$. At each temperature, fruit were placed in respiratory chambers $(20 \mathrm{~L})$ in a continuous flow $\left(100 \mathrm{~mL} \cdot \mathrm{min}^{-1)}\right.$ of humidified air. Nine cherimoyas were collected randomly before storage (prestored fruit) and for every subsequent sampling period, and used for immediately both nuclear magnetic resonance spectroscopy (NMR) experiments and physiological analyses. Another three cherimoyas were collected periodically, peeled, sliced, and frozen immediately in liquid nitrogen and stored at $-80^{\circ} \mathrm{C}$ until analyzed. Cherimoyas stored at the chilling temperature were analyzed after 3 and $9 \mathrm{~d}$ while, taking into account that the maximum storage period at ripening temperature is $\approx 5 \mathrm{~d}$, fruit stored at $20^{\circ} \mathrm{C}$ were sampled only after $3 \mathrm{~d}$.

NMR EXPERIMENTAL CONDITIONS. ${ }^{31} \mathrm{P}-\mathrm{NMR}$ spectra were recorded from prestored cherimoyas $(0 \mathrm{~d})$ and after 3 and $9 \mathrm{~d}$ of storage at $6^{\circ} \mathrm{C}$ in sealed chambers with continuous air flow. Fruit allowed to ripen at $20^{\circ} \mathrm{C}(3 \mathrm{~d})$ were also analyzed. Slices of mesocarp tissue ( $3 \mathrm{~g})$ were obtained using a manual dermatome. These intact slices were floated in a predetermined isotonic medium $\left[10 \mathrm{mmol} \cdot \mathrm{L}^{-1} 2\right.$ (N-morpholino)ethanesulfonic acid (Mes) buffer $\mathrm{pH}$ 6.5, 400 $\mathrm{mmol} \cdot \mathrm{L}^{-1} \mathrm{D}(+)$-glucose, $\left.0.1 \mathrm{mmol} \cdot \mathrm{L}^{-1} \mathrm{CaCl}_{2}, 2 \mathrm{mmol} \cdot \mathrm{L}^{-1} \mathrm{KCl}\right]$. Mesocarp strips $(2 \times 30 \mathrm{~mm})$ were cut from the slices, and placed in a Wilmad 10-mm NMR tube, carefully avoiding the formation of air pockets. The NMR tube containing the mesocarp strips and media was placed in a standard 10-mm NMR tube with two capillary tubes abutting the bottom of the NMR tube and connected to a peristaltic pump, and maintained at a constant temperature of $10^{\circ} \mathrm{C}$. For external Pi perfusion experiments, the isotonic medium, with or without $0.5 \mathrm{mmol} \cdot \mathrm{L}^{-1} \mathrm{NaH}_{2} \mathrm{PO}_{4}$, was aerated by air bubbling. For hypoxic perfusion experiments the isotonic medium was deoxygenated by bubbling with $\mathrm{N}_{2}$. The perfusion rate was $2 \mathrm{~mL} \cdot \mathrm{min}^{-1}$. Three spectra of nonperfused tissue were recorded for each sampling period at both temperatures. To avoid the influence of the experimental procedure, an acquisition time of 5 min was used for NMR spectra, with which similar spectra were recorded for nonperfused and air-perfused tissues of the same sample. The spectral width was $10,000 \mathrm{~Hz}$, and $16 \mathrm{k}$ data points were collected, employing a repetition time of $2.19 \mathrm{~s}$ and $\mathrm{a} 60^{\circ}$ flip angle. From 128 to 512 scans were accumulated. Methylenediphosphonic acid $\left(0.1 \mathrm{~mol} \cdot \mathrm{L}^{-1}\right.$ in $\mathrm{pH}$
8.9 Tris buffer solution) in a coaxial capillary tube was used as an internal reference $(0 \mathrm{ppm})$. The data were zero-filled to $32 \mathrm{k}$ points, line-broadened, and then Fourier-transformed. Zero order phasing was done, but first order was unnecessary. NMR spectra were recorded on a vertical superconducting narrow bore AMX-500 spectrometer (Bruker, Karlsruhe, Germany) operating at 202.4 $\mathrm{MHz}$ for $\mathrm{P}$.

Calibration curves were obtained to relate chemical shifts of intracellular ${ }^{31} \mathrm{P}$ resonances to $\mathrm{pH}$ changes. The calibration curve used for cytoplasmic $\mathrm{Pi}$ was built from a solution of $130 \mathrm{mmol} \cdot \mathrm{L}^{-1}$ $\mathrm{KCl}, 8 \mathrm{mmol} \cdot \mathrm{L}^{-1} \mathrm{MgCl}_{2}, 2 \mathrm{mmol} \cdot \mathrm{L}^{-1} \mathrm{CaCl}_{2}$, and $0.8 \mathrm{~mol} \cdot \mathrm{L}^{-1} \mathrm{D}(+)-$ glucose. A solution of $20 \mathrm{mmol} \cdot \mathrm{L}^{-1} \mathrm{KCl}, 5 \mathrm{mmol} \cdot \mathrm{L}^{-1}$ citric acid , 10 $\mathrm{mmol} \cdot \mathrm{L}^{-1}$ malic acid, and $30 \mathrm{mmol} \cdot \mathrm{L}^{-1} \mathrm{MgCl}_{2}$ was used to attempt to match vacuolar conditions. Five $\mathrm{mmol} \cdot \mathrm{L}^{-1} \mathrm{Pi}$ was added to both media and a $\mathrm{pH}$ series containing $5 \mathrm{mmol} \cdot \mathrm{L}^{-1} \mathrm{Mes}, 3-(\mathrm{N}-$ morpholino)propanesulfonic acid (MOPS) or Tricine buffers, depending on $\mathrm{pH}$, adjusted with $0.1 \mathrm{~mol} \cdot \mathrm{L}^{-1} \mathrm{KOH}$ was assayed. Solution $\mathrm{pH}$ was measured with a combination electrode standardized to $\mathrm{pH} 4$ and 7 and chemical shifts were plotted against $\mathrm{pH}$.

Tissue EXTRaCTs. Mesocarp tissues ( $1.5 \mathrm{~g}$ ) were treated with five volumes of $10 \%(\mathrm{w} / \mathrm{v})$ cold trichloroacetic acid to precipitate protein, followed by sonication on ice for $5 \mathrm{~min}$. The extract was neutralized using $4 \mathrm{~mol} \cdot \mathrm{L}^{-1} \mathrm{KOH}$ and the mixture was centrifuged for $30 \mathrm{~min}$ at $15,000 \mathrm{~g}_{n}\left(4^{\circ} \mathrm{C}\right)$, after which the supernatant was lyophilized and stored at $-80^{\circ} \mathrm{C}$. For NMR measurements, the dried homogenate was dissolved in $0.5 \mathrm{~mL}$ of deuterium oxide in a Wilmad $5 \mathrm{~mm}$ NMR tube. The $\mathrm{pH}$ was adjusted to 7.4 with deuterium chloride.

Phosphorus NMR spectra were recorded at $4{ }^{\circ} \mathrm{C}$ using a repetition time of $1 \mathrm{~s}$ and $6^{\circ}$ flip angle. The spectral width was $8196 \mathrm{~Hz}$, and $16 \mathrm{k}$ points were collected. Sixteen k scans were accumulated for each cell extract spectrum. Phosphorus chemical shifts were assigned by standardizing $\beta$-ATP $(-18.7 \mathrm{ppm})$. The data were zero-filled to $32 \mathrm{k}$ points, line-broadened, and then Fourier-transformed. Zero order phasing was done, but first order was unnecessary.

Physiological measurements. Respiration rate $\left(\mathrm{O}_{2}\right.$ consumption and $\mathrm{CO}_{2}$ production) and ethanol determination were analyzed as described previously (Muñoz et al., 1997). Briefly, both $\mathrm{O}_{2}$ consumption and $\mathrm{CO}_{2}$ production were measured using an automatic gas chromatographer (model 3700; Varian, Walnut Creek, CA) equipped with a thermal conductivity detector and a molecular sieve and Porapak Q column. Ethanol content was derived from the spectrophotometrically measured NADH produced by alcohol dehydrogenase $(\mathrm{ADH})$ in a coupled reaction (Boehringer Mannheim, Germany).

Oxygen respiration rates were expressed in $\mathrm{mmol} \cdot \mathrm{kg}^{-1} \cdot \mathrm{h}^{-1}, \mathrm{CO}_{2}$ rates in $\mathrm{mmol} \cdot \mathrm{kg}^{-1} \cdot \mathrm{h}^{-1}$, and ethanol content as $\mu \mathrm{mol} / 100 \mathrm{~g}$ fresh weight (FW). Total soluble solid content (SSC) was determined using a digital refractometer (Dbx 30; Atago Co. Ltd., Japan) at 20 ${ }^{\circ} \mathrm{C}$.

Pepc, MDH, AND me eXtraction AND aCtivities. Protein extracts for the PEPC assay were obtained by homogenizing ground, frozen mesocarp cherimoya tissue $(2.5 \mathrm{~g} \mathrm{FW})$ at $4{ }^{\circ} \mathrm{C}$ in $7.5 \mathrm{~mL}$ of 50 $\mathrm{mmol} \cdot \mathrm{L}^{-1}$ Tris- $\mathrm{HCl}$, $\mathrm{pH} 7.8$, containing $10 \mathrm{mmol} \cdot \mathrm{L}^{-1} \mathrm{MgCl}_{2}, 5$ $\mathrm{mmol} \cdot \mathrm{L}^{-1} \mathrm{NaHCO}_{3}, 2 \mathrm{mmol} \cdot \mathrm{L}^{-1}$ dithiothreitol (DTT), $0.25 \mathrm{mmol} \cdot \mathrm{L}^{-1}$ ethylene-diamino tetraacetic acid (EDTA), and 2\% (w/v) polyvinylpolypyrrolidone (PVPP). The homogenate was centrifuged at $20,000 g_{\mathrm{n}}$ for $30 \mathrm{~min}$ at $4^{\circ} \mathrm{C}$. PEPC activity was determined spectrophotometrically at $340 \mathrm{~nm}$ by coupling the reaction to $\mathrm{NADH}$ oxidation in the presence of $\mathrm{MDH}$ as described by Blanke and Notton (1991). 

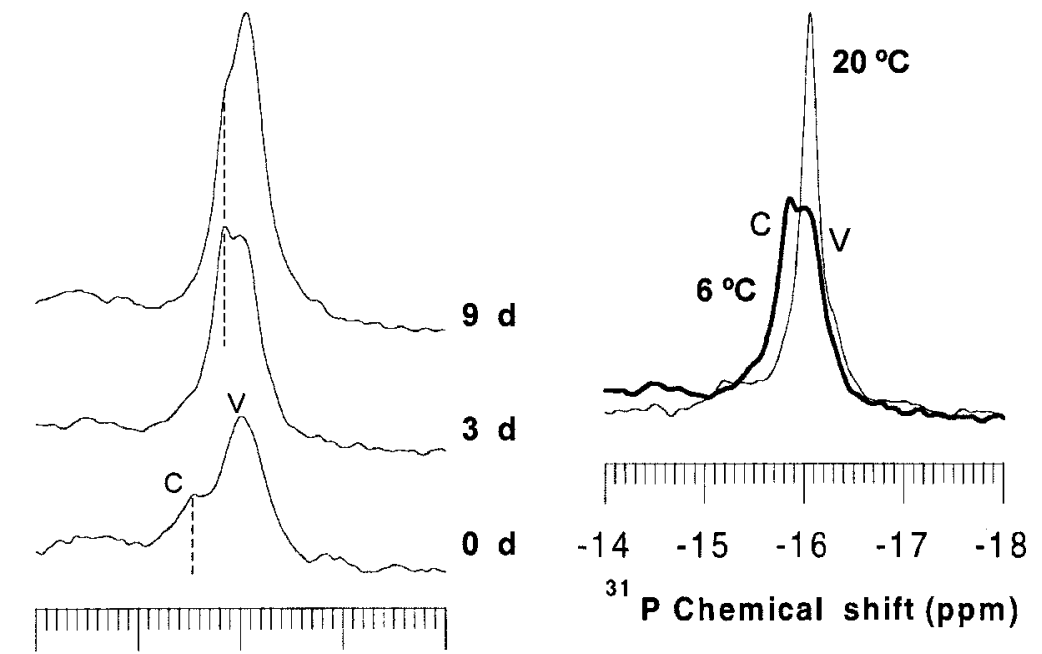

Fig. $2 .{ }^{31} \mathrm{P}$ chemical shift and intensity changes of cytoplasmic (C) and vacuolar (V) Pi pools of cherimoya fruit stored for $3 \mathrm{~d}$ at $6{ }^{\circ} \mathrm{C}$ (chilled fruit), marked by a heavy line, or at $20{ }^{\circ} \mathrm{C}$ (ripe fruit).

Fig. $1 .{ }^{31} \mathrm{P}$ chemical shift and intensity changes of cytoplasmic (C) and vacuolar (V) Pi pools of initial $(0 \mathrm{~d})$ cherimoya fruit and after 3 or $9 \mathrm{~d}$ storage at $6{ }^{\circ} \mathrm{C}$. Region covering cytoplasmic and vacuolar Pi of the whole spectra are enlarged to illustrate better detail. The dashed line indicates the chemical shift corresponding to cytoplasmic Pi. program, STSC, Rockville, Md.). Multiple variance analysis was employed to determine the significance of the data at $P \leq 0.05$.

\section{Results}

EFFECT OF CHILLING TEMPERATURE ON CYTOPLASMIC AND VACULAR PI POOLS. To identify the cytoplasmic and vacuolar Pi-NMR peaks in prestored cherimoya fruit, mesocarp tissues were air-perfused with an isotonic medium or with deoxygenated $\left(\mathrm{N}_{2}-\right.$ bubbled) medium. When tissues were perfused with deoxygenated medium for $5 \mathrm{~min}$, the peak which moved upfield, indicating an acidification of $0.65 \pm$ $0.07 \mathrm{pH}$ units below the control values, was assigned to cytoplasmic $\mathrm{Pi}$; moreover the chemical shift ceased to change when tissues were bubbled with $\mathrm{N}_{2}$ during perfusion for $20 \mathrm{~min}$ (data not presented). The deoxygenated medium had no apparent effect on the chemical shift of peak assigned to vacuolar Pi.

The phosphorus NMR spectra of cherimoyas after storage at $6^{\circ} \mathrm{C}$ for 0,3 or $9 \mathrm{~d}$ (Fig. 1), which displays and expands the region (between -15 and $-16 \mathrm{ppm}$ ) covering cytoplasmic and vacuolar $\mathrm{Pi}$, shows the
Protein extracts for MDH and ME assays were obtained by homogenizing ground, frozen mesocarp cherimoya tis- sue $(2.5 \mathrm{~g} \mathrm{FW})$ at $4{ }^{\circ} \mathrm{C}$ in $10 \mathrm{~mL}$ of $0.1 \mathrm{~mol} \cdot \mathrm{L}^{-1}$ Bicine- $0.1 \mathrm{~mol} \cdot \mathrm{L}^{-1}$ MOPS, pH 7.0 containing $0.3 \mathrm{mmol} \cdot \mathrm{L}^{-1} \mathrm{DTT}, 4 \mathrm{mmol} \cdot \mathrm{L}^{-1}$ EDTA, $5 \%(\mathrm{v} / \mathrm{v})$ polyethylene glycol (PEG), and $1 \%(\mathrm{w} / \mathrm{v})$ polyvinylpyrrolidone (PVP). MDH activity was assayed by following oxidation of the reduced form of nicotinamide adenine dinucleotide (NADH), in a reaction mixture containing $0.1 \mathrm{~mol} \cdot \mathrm{L}^{-1}$ MOPS buffer, $\mathrm{pH} 7.0,3.33$ $\mathrm{mmol} \cdot \mathrm{L}^{-1}$ oxalacetic acid (OAA), and 0.2 $\mathrm{mmol} \cdot \mathrm{L}^{-1} \mathrm{NADH}$ at $27^{\circ} \mathrm{C}$. ME activity was assayed by monitoring production of the reduced form of nicotinamide adenine dinucleotide 3'phosphate (NADPH), expressed as an increase in absorbance at $340 \mathrm{~nm}$, in a reaction mixture containing $0.1 \mathrm{~mol} \cdot \mathrm{L}^{-1}$ MOPS buffer, $\mathrm{pH} 7.0,17$ $\mathrm{mmol} \cdot \mathrm{L}^{-1}$ sodium malate, $4.5 \mathrm{mmol} \cdot \mathrm{L}^{-1} \mathrm{MnSO}_{4}$, and $0.7 \mathrm{mmol} \cdot \mathrm{L}^{-1} \mathrm{NADP}^{+}$at $25^{\circ} \mathrm{C}$. Protein concentration was measured by the method of Bradford (1976).

Statistical analyses. Data from at least three replicates per sample were subjected to analysis of variance procedures (Statgraphics

Fig. $3 .{ }^{31} \mathrm{P}-\mathrm{NMR}$ spectra of mesocarp tissue from cherimoyas stored at (A) $6{ }^{\circ} \mathrm{C}$ and from cherimoyas stored at (B) 20 ${ }^{\circ} \mathrm{C}$ perfused sequentially with $\mathrm{a}=$ aerated isotonic medium (initial conditions); $\mathrm{b}=$ for $20 \mathrm{~min}$ with aerated isotonic medium containing $0.5 \mathrm{mmol} \cdot \mathrm{L}^{-1} \mathrm{NaH}_{2} \mathrm{PO}_{4} ; \mathrm{d}=$ for 50 min with aerated isotonic medium (without phosphate); $\mathrm{c}=$ control (external isotonic Na-phosphate medium). All the NMR spectra were recorded with an acquisition time of $5 \mathrm{~min}$. The dashed line indicates the chemical shift corresponding to cytoplasmic $\mathrm{Pi}$. The peaks marked with an asterisk (*) are the resonance of external Pi. Regions covering cytoplasmic and vacuolar $\mathrm{Pi}$ in a) and b) are enlarged to show better detail.

chemical shift and intensity changes at both resonances. According to our spectra obtained from cherimoya tissues perfused under the different experimental conditions mentioned above, and the reported literature observations (Roberts et al., 1982) about the relative amounts of vacuolar and cytoplasmic pools, the higher and upfield (rightwards in the figure) peak, indicative of a more acidic environment, was assigned to vacuolar $\mathrm{Pi}(\mathrm{V})$ and the smaller downfield peak to cytoplasmic $\mathrm{Pi}(\mathrm{C})$. The trend observed after $3 \mathrm{~d}$ storage at $6{ }^{\circ} \mathrm{C}$, as indicated by cytoplasmic Pi pool displacement, $6^{\circ} \mathrm{C}$

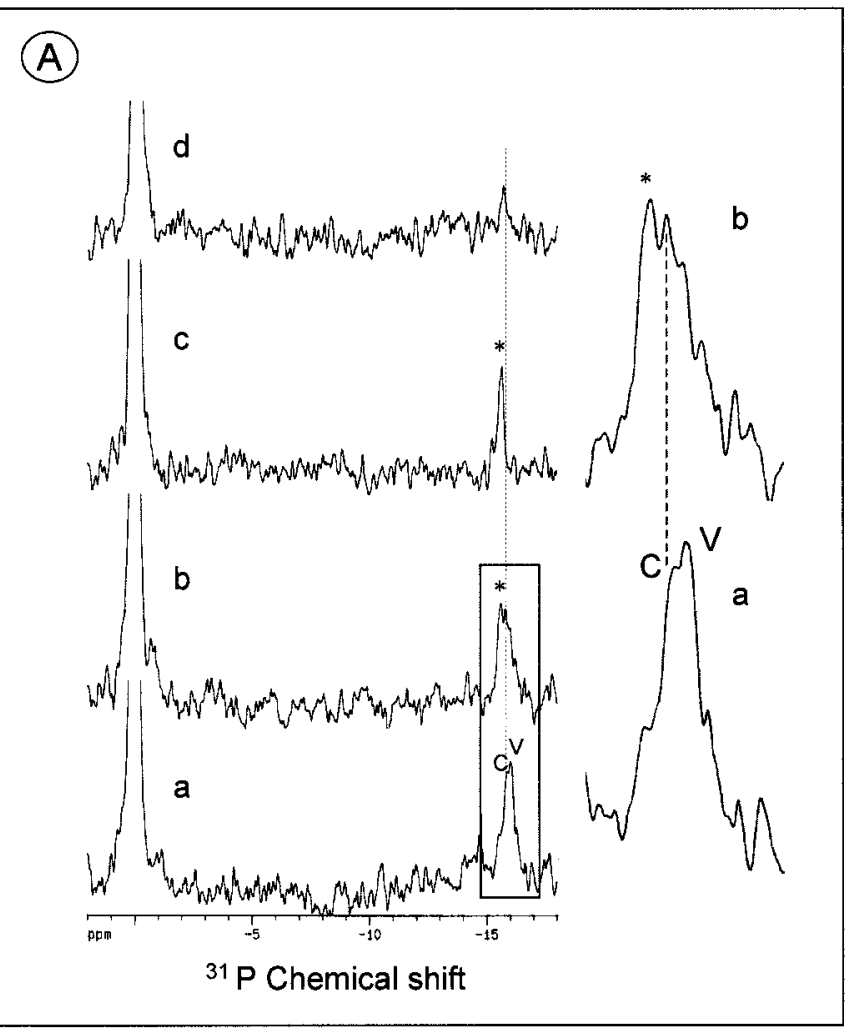

$20^{\circ} \mathrm{C}$

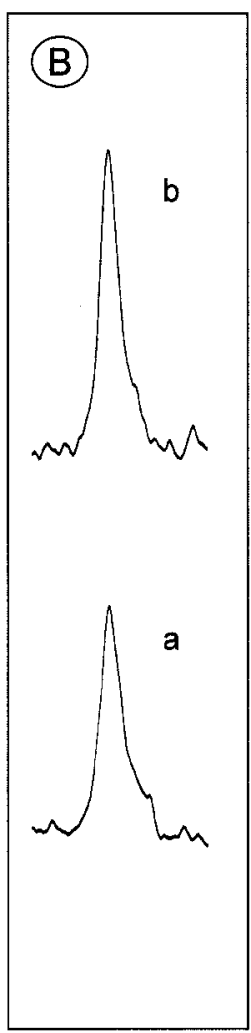



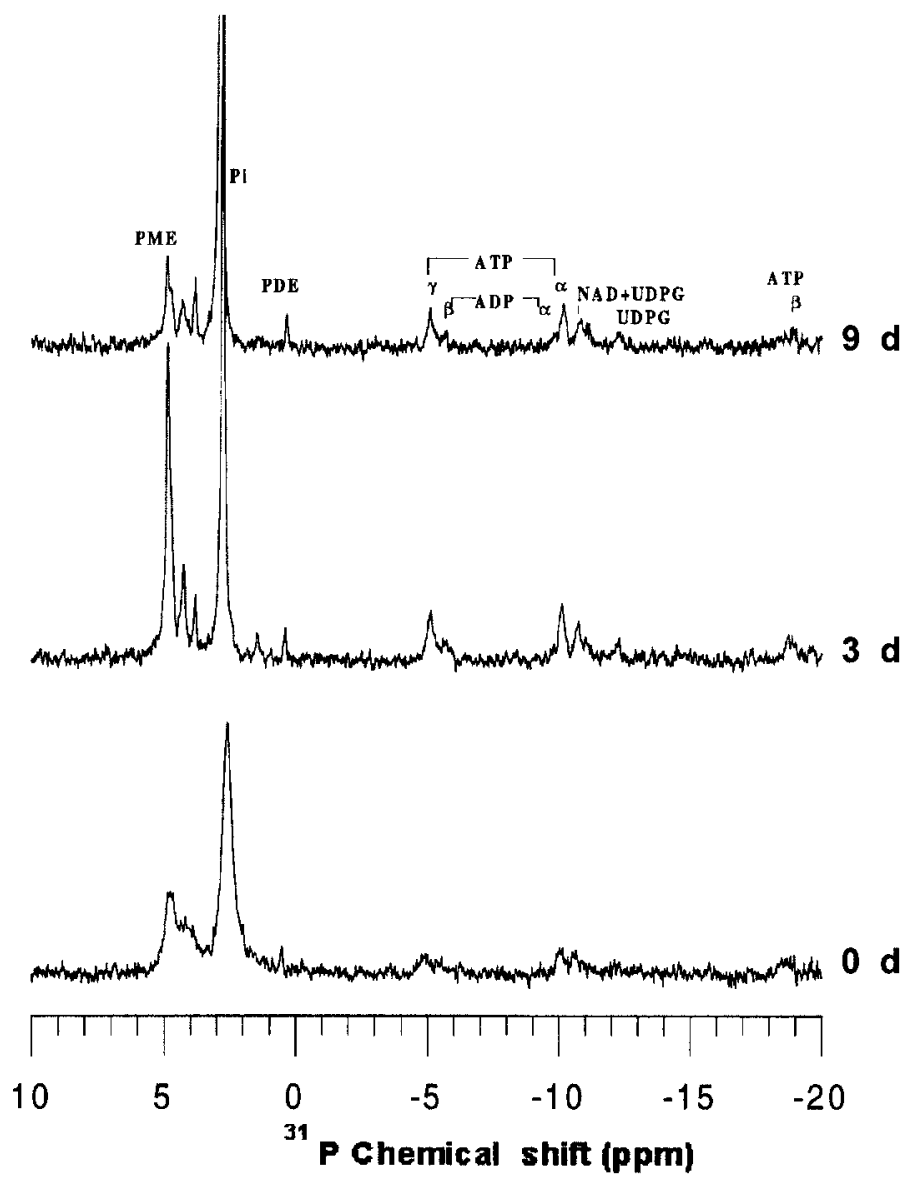

Fig. 4. ${ }^{31} \mathrm{P}-\mathrm{NMR}$ spectra of perchloric acid extracts, adjusted to $\mathrm{pH} 7.4$, from cherimoya fruit stored at $6{ }^{\circ} \mathrm{C}$. The abbreviations of the resonances are PME $=$ phosphomonoesters, $\mathrm{Pi}=$ inorganic phosphate, $\mathrm{PDE}=$ phosphodiesters, $\mathrm{ATP}=$ adenine nucleoside triphosphate, $\mathrm{ADP}=$ adenine nucleoside diphosphate, NAD $=$ nicotinamide adenine dinucleotide, and UDPG $=$ uridine diphosphate glucose . The chemical shifts are referenced to $\beta$-ATP $(-18.7 \mathrm{ppm})$.

was an upfield shift, reflecting cell acidification, which was estimated to account for an average decrease of $0.72 \pm 0.08 \mathrm{pH}$ units, by using the calibration curve. After $9 \mathrm{~d}$ storage at low temperature the Pi cytoplasmic peak was detectable as a shoulder in the spectrum (Fig. 1), but its chemical shift value did not change, indicating that low cytoplasmic $\mathrm{pH}$ continued to prevail after $9 \mathrm{~d}$ storage at $6^{\circ} \mathrm{C}$. No change was observed in the vacuolar chemical shift throughout the storage period.

${ }^{31} \mathrm{P}-\mathrm{NMR}$ experiments also provided valuable information on Pipool content. The cytoplasmic Pi pool under $6^{\circ} \mathrm{C}$ storage conditions contrasts with observations for fruit stored for $3 \mathrm{~d}$ at $20^{\circ} \mathrm{C}$ (Fig. 2). Storage at 20 ${ }^{\circ} \mathrm{C}$ was associated with a sharp rise in the vacuolar Pi pool.

EFFECT OF CHILLING TEMPERATURE ON PHOSPHATE UPTAKE. To test the effect of temperature storage on phosphate uptake, mesocarp tissue of cherimoyas stored in respiration chambers at 6 or $20^{\circ} \mathrm{C}$ for $3 \mathrm{~d}$ was perfused with phosphate-containing medium and the corresponding spectra were recorded. After 20 min of perfusion of chilled tissues with phosphate-containing medium (Fig. 3Ab), the intensity of cytoplasmic Pi resonance increased over the initial value (Fig. 3Aa) and that of the vacuole Pi resonance remained the same or decreased. On the contrary, when mesocarp tissues from ripe fruit stored at $20^{\circ} \mathrm{C}$ were perfused with phosphate-containing medium for 20 min, no accumulation of cytoplasmic Pi was observed (Fig. 3B).

${ }^{31} \mathrm{P}$ resonance from the external $\mathrm{Na}$-phosphate-containing medium buffered at $\mathrm{pH} 6.5$ was located down from the cytoplasmic Pi peak and remained nearly unchanged during the uptake experiment, and was considered as a suitable control (Fig. 3Ac). Under decreasing Pi availability, when the chilled mesocarp tissues were subsequently perfused with the normal phosphate-free medium for 50 min (Fig. 3Ad), a general decline in Pi intensity was observed. Under these conditions, the highest Pi pool was located in the cytoplasm, whereas the vacuolar peak declined steadily.

EFFECT OF CHILLING TEMPERATURE ON THE POOL OF PHOSPHORYLATED METABOLITES. Since data accumulation times ( $5 \mathrm{~min}$ ) were too short to visualize other phosphorylated metabolites, whose concentration was lower, ${ }^{31} \mathrm{P}-\mathrm{NMR}$ spectra were obtained for cherimoya perchloric acid extracts after storage at $6^{\circ} \mathrm{C}$ and the peaks due to intracellular phosphorus metabolites observed in the spectra were assigned (Fig. 4). Whereas ADP was held at steady-state levels, the amount of ATP (mainly $\alpha$ - and $\gamma$-ATP) rose sharply after storage at $6^{\circ} \mathrm{C}$. The ATP/ADP ratio consequently increased in chilled fruit (Table 1). By contrast, the phosphorylation potential (ATP/ADP.Pi) declined sharply in cherimoyas stored at $6^{\circ} \mathrm{C}$. Contrary to observations for chilled fruit, the pool of total nucleotides decreased beyond the point of NMR-detection in fruit stored at $20^{\circ} \mathrm{C}$.

RESPIRATORY AND MALIC ACID METABOLISM IN CHERIMOYA FRUIT STORED AT $6^{\circ} \mathrm{C}$. Cherimoyas stored at $6^{\circ} \mathrm{C}$ exhibited a low respiration rate. Oxygen consumption and $\mathrm{CO}_{2}$ production in fruit after $3 \mathrm{~d}$ storage were $19.5 \%$ and $11.4 \%$, respectively, of ripe fruit levels (3 $\mathrm{d}$ at $20^{\circ} \mathrm{C}$ ) (Fig. 5). The low respiration rate $\left(\mathrm{CO}_{2}\right.$ production) remained fairly constant in fruit throughout the trial period $(9 \mathrm{~d})$. While in ripe fruit, the respiration quotient (RQ) values were above one, storage at $6^{\circ} \mathrm{C}$ resulted in a sharp decline in RQ. Once the low respiration rate in fruit stored at $6^{\circ} \mathrm{C}$ was established, the fermentation pathway was studied by estimating ethanol production (Fig. 6). Although ethanol content increased slightly in chilled fruit to values of $32 \mu \mathrm{mol} / 100 \mathrm{~g} \mathrm{FW}$, this value was lower than in ripe fruit stored at $20^{\circ} \mathrm{C}$. The total soluble solid content in chilled fruit at the end of the trial period, however, was slightly lower than that found in ripe fruit at $20^{\circ} \mathrm{C}$.

Prestored fruit (day 0) showed very high PEPC and MDH activities $\left(25.9 \pm 3.3 \mu \mathrm{mol} \cdot \mathrm{min}^{-1} \cdot \mathrm{mg}^{-1}\right.$ protein and $4.8 \pm 0.3$ $\mathrm{mmol} \cdot \mathrm{min}^{-1} \cdot \mathrm{mg}^{-1}$ protein, respectively) (Table 2 ). Contrary to

Table 1. Changes in the ATP/ADP ratio, phosphorylation potential (ATP/ADP.Pi), pool of adenine nucleotides, and Pi in cherimoya fruit stored at ripening $\left(20^{\circ} \mathrm{C}\right)$ and chilling $\left(6^{\circ} \mathrm{C}\right)$ temperatures.

\begin{tabular}{|c|c|c|c|c|c|c|c|}
\hline \multirow{2}{*}{$\begin{array}{l}\text { Storage } \\
\text { treatment }\end{array}$} & \multirow[b]{2}{*}{ ATP/ADP } & \multirow[b]{2}{*}{ ATP/ADP.Pi } & \multicolumn{3}{|c|}{ ATP } & \multirow[b]{2}{*}{ ADP } & \multirow[b]{2}{*}{$\mathrm{Pi}$} \\
\hline & & & $\gamma$ & $\alpha$ & $\beta$ & & \\
\hline Initial (0 d) & 3.78 & 0.38 & 0.76 & 0.97 & 0.65 & 0.63 & $10.00^{z}$ \\
\hline 3 d at $6{ }^{\circ} \mathrm{C}$ & 6.25 & 0.17 & 1.94 & 2.19 & 0.93 & 0.81 & 36.31 \\
\hline 9 d at $6^{\circ} \mathrm{C}$ & 6.49 & 0.13 & 1.50 & 1.69 & 0.77 & 0.61 & 49.56 \\
\hline 3 d at $20^{\circ} \mathrm{C}$ & --- & --- & $\mathrm{ND}^{\mathrm{y}}$ & ND & ND & ND & 28.36 \\
\hline
\end{tabular}

${ }^{\mathrm{Z}}$ Data are presented as relative to initial Pi peak area of mesocarp tissue.

${ }^{\mathrm{N} D}=$ not detectable. 
$20^{\circ} \mathrm{C}$
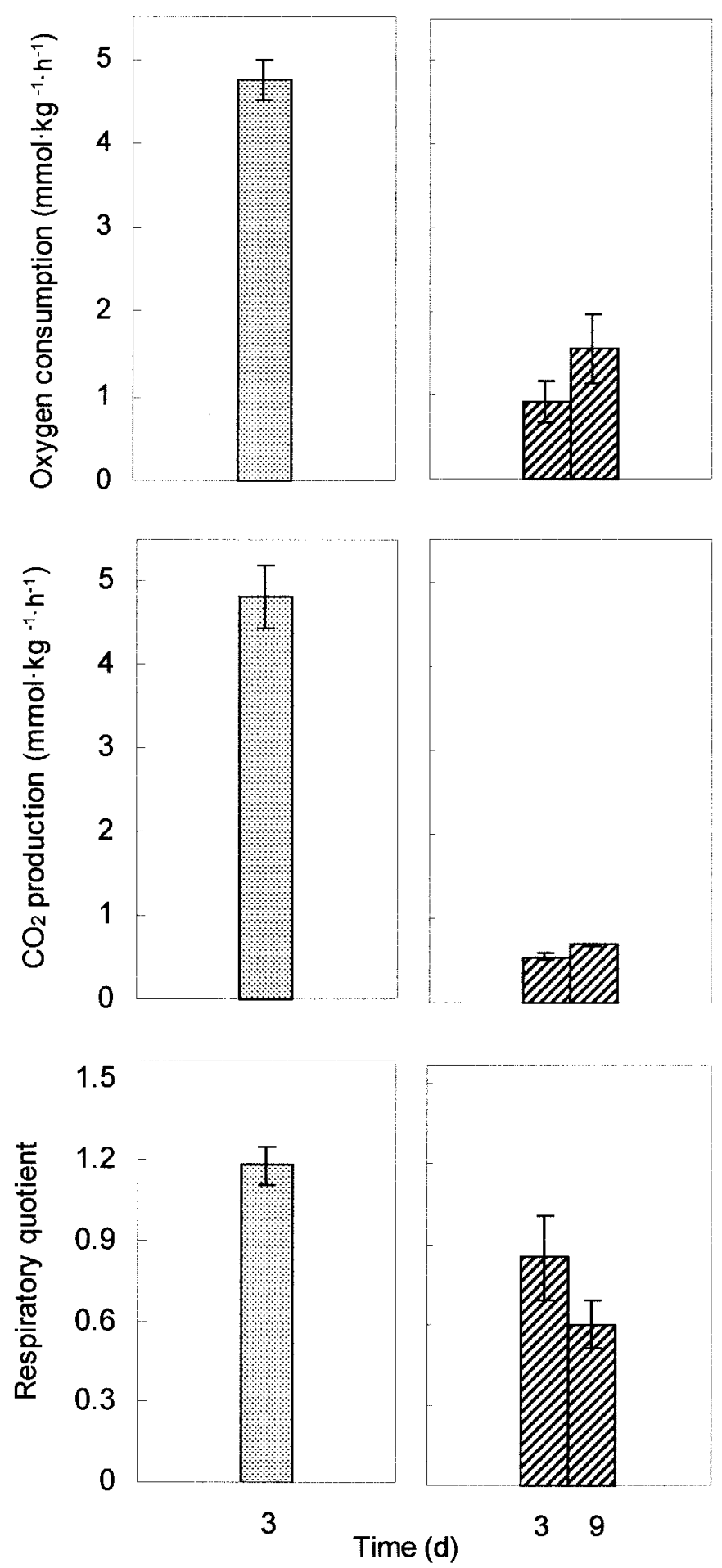

Fig. 5. Changes in respiration rate $\left(\mathrm{O}_{2}\right.$ consumption and $\mathrm{CO}_{2}$ production $)$ and respiratory quotient of cherimoyas stored for 3 or $9 \mathrm{~d}$ at $6^{\circ} \mathrm{C}$, compared with ripe fruit levels $\left(3 \mathrm{~d}\right.$ at $\left.20^{\circ} \mathrm{C}\right)$. Data are means of three different experiments $(n=6)$ and vertical bars represent \pm sE.

patterns in fruit ripened at $20^{\circ} \mathrm{C}$, after $3 \mathrm{~d}$ storage at $6^{\circ} \mathrm{C}, \mathrm{PEPC}$ activity was higher. Minor changes were detected in MDH activity in fruit stored at both ripening and chilling temperatures. The activity of $\mathrm{NADP}^{+}-\mathrm{ME}$, a cytosolic enzyme responsible for malate catabolism, did not significantly change $(P \leq 0.05)$ in low temperature storage.
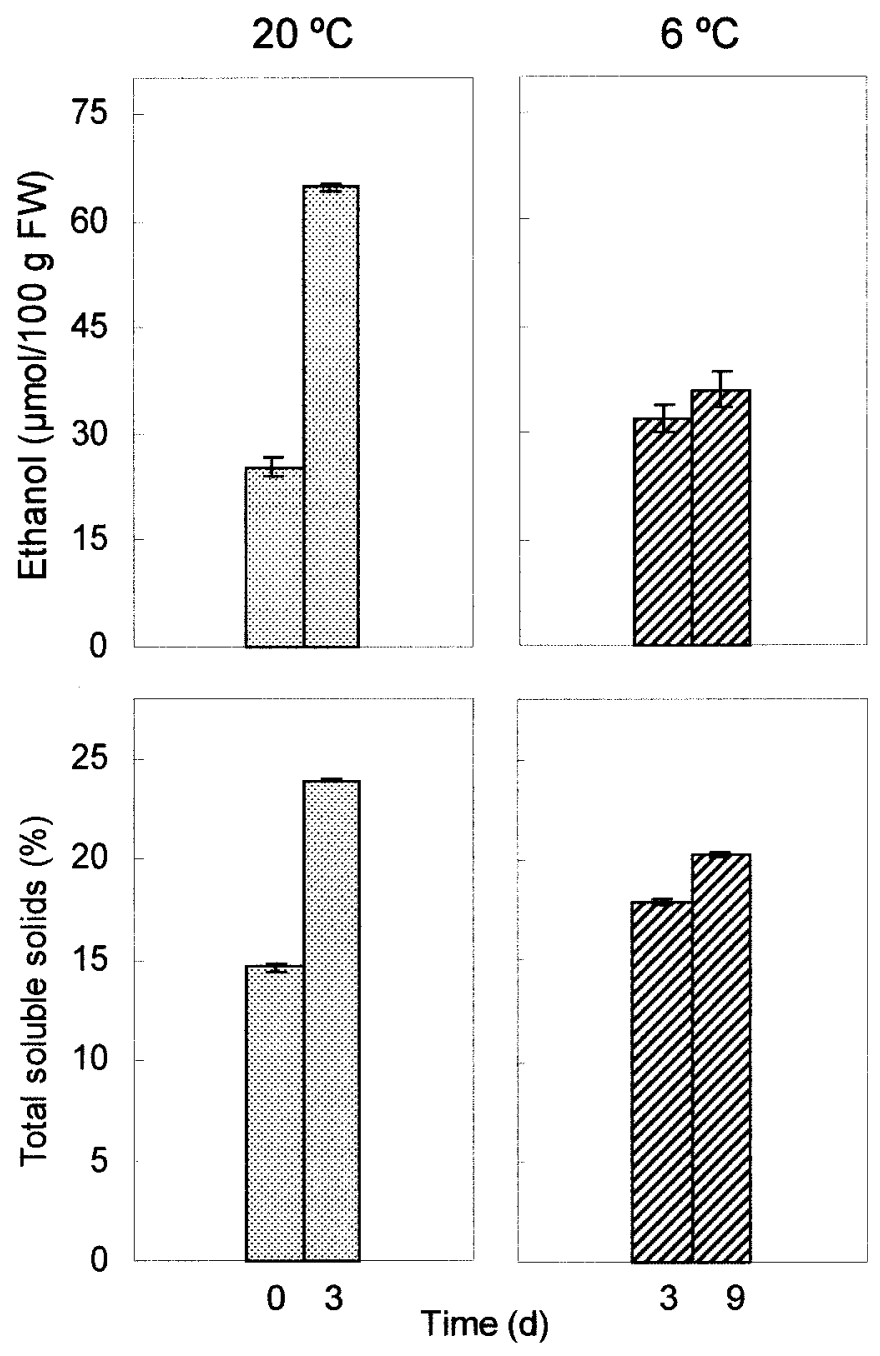

Fig. 6. Changes in ethanol and total soluble solids in cherimoya fruit stored for 3 or $9 \mathrm{~d}$ at $6{ }^{\circ} \mathrm{C}$, compared with initial $(0 \mathrm{~d})$ and ripe fruit $\left(3 \mathrm{~d}\right.$ at $\left.20^{\circ} \mathrm{C}\right)$ levels. Data are means of three different experiments $(n=6)$ and vertical bars represent \pm SE.

\section{Discussion}

The present ${ }^{31} \mathrm{P}-\mathrm{NMR}$ experiments showed that under chilling temperature storage, the cytoplasmic $\mathrm{Pi}$ pool changes in both chemical shift and intensity. After storage of cherimoyas at $6^{\circ} \mathrm{C}$ for $3 \mathrm{~d}$, cytoplasmic $\mathrm{pH}$ decreased $0.72 \mathrm{pH}$ units, confirming that chilling temperature causes acidosis. Induced cytoplasmic acidosis has also been observed in mesophyll cells from leaves of different species, which are all extremely sensitive to chilling (Yoshida, 1994). In previous papers (Merodio et al., 1998; Muñoz et al., 1999) we reported indirect evidence of cytosolic acidification in chilled cherimoyas. With respect to the Pi pool, ${ }^{31} \mathrm{P}-\mathrm{NMR}$ experiments provided valuable information about accumulation of $\mathrm{Pi}$ in the cytoplasm of tissues held at $6^{\circ} \mathrm{C}$ (chilling temperature) which were different from tissues held at $20^{\circ} \mathrm{C}$ (ripening temperature). In ripe cherimoya fruit $\left(20{ }^{\circ} \mathrm{C}\right)$, there was vacuolar $\mathrm{Pi}$ accumulation, concurrent with low cytoplasmic Pi levels, a result also reported by Bennett et al. (1987) for ripe avocado (Persea americana Mill.) fruit.

Moreover, results obtained when fruit mesocarp tissues were perfused with a phosphate medium confirm that external Pi did not enter the vacuole in fruit stored at $6^{\circ} \mathrm{C}$ in contrast to those obtained with cherimoyas stored at $20{ }^{\circ} \mathrm{C}$, where enhanced vacuolar $\mathrm{Pi}$ 
Table 2. Changes in phosphoenolpyruvate carboxylase (PEPC), malic dehydrogenase (MDH), and malic enzyme (ME) activities in cherimoya fruit stored at ripening $\left(20^{\circ} \mathrm{C}\right)$ and chilling $\left(6^{\circ} \mathrm{C}\right)$ temperatures. Data ${ }^{\mathrm{Z}}$ are means $\pm \mathrm{SE}$ of three separate experiments $(\mathrm{n}=6)$.

\begin{tabular}{|c|c|c|c|}
\hline $\begin{array}{l}\text { Storage } \\
\text { treatment }\end{array}$ & $\begin{array}{c}\text { PEPC } \\
\left(\mu \mathrm{mol} \cdot \mathrm{min}^{-1} \cdot \mathrm{mg}^{-1}\right)\end{array}$ & $\begin{array}{c}\text { MDH } \\
\left(\mathrm{mmol} \cdot \mathrm{min}^{-1} \cdot \mathrm{mg}^{-1}\right)\end{array}$ & $\begin{array}{c}\mathrm{ME} \\
\left(\mathrm{mmol} \cdot \mathrm{min}^{-1} \cdot \mathrm{mg}^{-1}\right)\end{array}$ \\
\hline$\overline{\text { Initial (0 d) }}$ & $25.9 \mathrm{a}(3.3)^{\mathrm{z}}$ & $4.79 \mathrm{a}(0.34)$ & $0.15 \mathrm{a}(0.004)$ \\
\hline 3 d at $6{ }^{\circ} \mathrm{C}$ & $32.1 \mathrm{~b}(1.7)$ & $4.12 \mathrm{a}(0.38)$ & 0.13 a (0.004) \\
\hline $3 \mathrm{~d}$ at $20^{\circ} \mathrm{C}$ & 5.9 c (1.0) & $4.19 \mathrm{a}(0.14)$ & 0.09 a $(0.005)$ \\
\hline
\end{tabular}

${ }^{\mathrm{z}}$ Mean separation within columns (by LSD test) at $P \leq 0.05$.

accumulation took place. These data agree with the decrease in permeability of tonoplast-like vesicles in tomato (Lycopersicon esculentum Mill.) cells at chilling temperature observed by DuPont and Mudd (1985).

ATP levels during low temperature storage were high compared with fruit stored at $20^{\circ} \mathrm{C}$ or with prestored fruit (day 0). High ATP levels were also observed by Wilson and McMurdo (1981) in leaves stored at low temperature. The high steady state level of ATP in chilled fruit and the decrease in the ATP/ADP.Pi ratio during storage at $6^{\circ} \mathrm{C}$ could indicate deficiencies in ATP-using processes.

In contrast with cherimoyas maintained at the $20^{\circ} \mathrm{C}$ ripening temperature, respiration rate was very low in cherimoyas stored at the $6^{\circ} \mathrm{C}$ chilling temperature. Total soluble solids increased in chilled fruit, although the levels were lower than in ripe fruit. It has been proposed that chilling sensitive plants compensate for impaired mitochondrial function by shifting their metabolism from aerobic to anaerobic respiration (Levitt, 1980). This strategy is an important component of the acclimation to hypoxic conditions, another environmental stress that prevents mitochondrial activity (Roberts et al., 1984b). However, in this study we found that the ethanol content in chilled fruit did not increase to the levels observed in ripe fruit. According to the evolution of respiratory metabolism during storage at chilling temperature (RQ below unity), it would appear that a high rate of carboxylation vs. decarboxylation of organic acids might occur in chilled fruit. To test this possibility, PEPC, MDH, and ME activities were determined. While minor changes were detected in $\mathrm{MDH}$ and $\mathrm{ME}$ activities at both ripening and chilling temperature, PEPC activity increased after $3 \mathrm{~d}$ at $6{ }^{\circ} \mathrm{C}$ but decreased after $3 \mathrm{~d}$ at $20^{\circ} \mathrm{C}$. Taking into account the important role of this cytoplasmic enzyme in determining levels of $\mathrm{Pi}$, the high PEPC activity in chilled fruit may, along with other causes, account for the high Pi levels in the cytoplasm of these fruit.

Overall, results herein seem to indicate that cherimoyas stored at chilling temperature are unable to accommodate to high acid metabolism in the cytoplasmic environment. Further investigations are needed to determine the beneficial effect of specific postharvest technologies to restore the intracellular $\mathrm{pH}$ homeostasis disrupted by chilling temperature storage.

\section{Literature Cited}

Alique, R., J.P. Zamorano, M.L. Calvo, C. Merodio, and J.L. De La Plaza. 1994. Tolerance of cherimoya (Annona cherimola Mill.) to cold storage. J. Amer. Soc. Hort. Sci. 119:524-528.

Bennett, A.B., G.M. Smith, and B.G. Nichols. 1987. Regulation of climateric respiration in ripening avocado fruit. Plant Physiol. 83:973-976.

Blanke, M.M. and B.A. Notton. 1991. Kinetics and physiological significance of photosynthetic phosphoenolpyruvate carboxylase in avocado fruit. J. Plant Physiol. 137:553-558.

Bradford, M. 1976. A rapid and sensitive method for the quantification of microgram quantities of protein utilizing the principle of protein-dye binding. Anal. Biochem. 72:248-254.

Crawford, L.A., A.W. Bown, K.E. Breitkreuz, and F.C. Guinel. 1994. The synthesis of $\gamma$-aminobutyric acid in response to treatments reducing cytosolic $\mathrm{pH}$. Plant
Physiol. 104:865-871.

DuPont, F.M. and J.B. Mudd. 1985. Acclimation to low temperature by microsomal membranes from tomato cell cultures. Plant Physiol. 77:74-78.

Guern, J., Y. Mathieu, M. Pean, C. Pasquier, J.C. Boloeil, and J.Y. Lallemand. 1986. Cytoplasmic pH regulation in Acer pseudoplatanus cells. Plant Physiol. 82:840 845 .

Kurkdjian, A. and J. Guern. 1989. Intracellular pH: Measurement and importance in cell activity. Annu. Rev. Plant Physiol. Plant Mol. Biol.40:271-303.

Lapous, D., Y. Mathieu, J. Guern, and C. Laurière. 1998. Increase of defense gene transcripts by cytoplasmic acidification in tobacco cell suspensions. Planta 205:452-458

Levitt, J.1980. Responses of plants to environmental stresses, vol. 1. Chilling, freezing, and high temperature stresses. Academic Press, New York.

Lüttge, U. and R. Ratajczak. 1997. The physiology, biochemistry and molecular biology of the plant vacuolar ATPase, p. 253-296. In: R. Leigh and D. Sanders (eds.). Advances in botanical research, vol. 25, The plant vacuole. Academic Press, Oxford, United Kingdom..

Lyons, J.M. 1973. Chilling injury in plants. Annu. Rev. Plant Physiol. 24:445-466. Merodio, C. and J.L. De La Plaza. 1997. Cherimoya, p. 269-293. In: S.K. Mitra (ed.). Postharvest physiology and storage of tropical and subtropical fruits. CAB Intl., Wallingford, United Kingdom.

Merodio, C., M.T. Muñoz, B. Del Cura, M.D. Buitrago, and M.I. Escribano. 1998. Effect of high $\mathrm{CO}_{2}$ level on the titres of $\gamma$-aminobutyric acid, total polyamines and some pathogenesis-related proteins in cherimoya fruit stored at low temperature. J. Exp. Bot. 49:1339-1347.

Muñoz, M.T., P.Aguado, N.Ortega, M.I. Escribano, and C.Merodio. 1999. Regulation of ethylene and polyamine synthesis by elevated carbon dioxide in cherimoya fruit stored at ripening and chilling temperatures. Aust. J. Plant Physiol. 26:201-209.

Muñoz, M.T., M.I.Escribano, and C. Merodio. 1997. Ethanolic metabolism in cherimoya fruit during storage at ambient and under high $\mathrm{CO}_{2}$ atmospheres. J. Hort. Sci. 72:363-370.

Nanos, G.D. and A.A. Kader. 1993. Low $\mathrm{O}_{2}$-induced changes in $\mathrm{pH}$ and energy charge in pear fruit tissue. Postharvest Biol. Technol. 3:285-291.

Raison, J.K. and G.R. Orr. 1990. Proposals for a better understanding of the molecular basis of chilling injury, p. 145-164. In: C.Y. Wang (ed.). Chilling injury of horticultural crops. CRC Press, Inc., Boca Raton, Fla.

Ratcliffe, R.G. 1994. NMR studies of higher plants and algae. Adv. Bot. Res. 20:44123.

Roberts, J.K.M., J. Callis, O. Jardetzky, V. Walbot, and M. Freelling. 1984a. Cytoplasmic acidosis as a determinant of flooding intolerance in plants. Proceed. Nat. Acad. Sci. USA. 81:6029-6033.

Roberts, J.K.M., J. Callis, D. Wemmer, V. Walbot, and O. Jardetzky. 1984b. Mechanism of cytoplasmic $\mathrm{pH}$ regulation in hypoxic maize root tips and its role in survival under hypoxia. Proc. Natl. Acad. Sci. USA 81:379-3383.

Roberts, J.K.M., D. Wemmer, P.M. Ray, and O. Jardetzky. 1982. Regulation of cytoplasmic and vacuolar $\mathrm{pH}$ in maize root tips under different experimental conditions. Plant Physiol. 69:1344-1347.

Siriphanich, J. and A.A. Kader. 1986. Changes in cytoplasmic and vacuolar pH in harvest lettuce tissue as influenced by $\mathrm{CO}_{2}$. J. Amer. Soc. Hort. Sci. 111:73-77.

Smith, F.A. and J.A. Raven. 1979. Intracellular pH and its regulation. Ann. Rev. Plant Physiol. 30:289-311.

Wang, C.Y. 1982. Physiological and biochemical responses of plants to chilling stress. HortScience 17:173-186.

Wilson, J.M. and A.C. McMurdo. 1981. Chilling injury in plants, p. 145-172. In: G.J. Morris and A. Clarke (eds). Effects of low temperatures on biological membranes. Academic Press, London.

Yoshida, S. 1994. Low temperature-induced cytoplasmic acidosis in cultured mung bean (Vigna radiata [L.] Wilczek) cells. Plant Physiol. 104:1131-1138. 